\title{
EFFECT OF FISH FREEZING ON SELECTED PARAMETERS OF SMOKED PRODUCT QUALITY
}

\author{
KILIBARDA NATAŠA*, BALTIĆ ŽM"**, DIMITRIJEVIĆ MIRJANA**, KARABASIL N** \\ and KIŠKAROLJ F* \\ *Veterinary Specialist Institute, Subotica \\ ${ }^{*}$ Faculty of Veterinary Medicine, University of Belgrade, Serbia
}

(Received 1. December 2008)

In the circumstances of small processing facilities for smoked fish production, and a particularly good fishing season, there occurs the necessity for freezing the catch in order to process it and preserve it in this way, at times when the season is not so good. To this end, the goal of our research was to examine the effect of freezing fish on the selected parameters of cold smoked, vacuum-packed trout fillets. To conduct the experiment, two groups of trout were formed: the control one, out of fresh fish, and the experimental one, out of previously frozen fish. In the course of a three week period of smoked fish storage at the temperature of $4^{\circ} \mathrm{C}$ the variation of the total number of bacteria, and the total number of lactobacilli were monitored. Also, at the end of processing, the content value of water and salt were determined, as well as the content value of salt in the water phase, and $a_{w}$ value (water activity). By testing the bacteriological status of two groups of products during the storage period, it was determined that the total number of both bacteria and lactobacilli was smaller in the samples produced from frozen fish. The average content value of water and $\mathrm{NaCl}$, as well as the salt content value in the water phase, in the vacuum-packed, smoked fillets produced from frozen fish was statistically, considerably larger than the content value of water, salt, and salt content value in the water phase in the samples manufactured from fresh fish. Our research findings show that using the raw material that was previously frozen for producing smoked fish fillets is not only appropriate, but also recommended.

Key words: freezing, smoked fish, quality

\section{INTRODUCTION}

Smoked fish is a desirable and highly appreciated product on the world and European market. It is present with up to $17 \%$ out of the total supply on the French market. The production of cold smoked fish has a long tradition based on getting a mildly salted product, smoked at temperatures lower than $32^{\circ} \mathrm{C}$, which is used in human nutrition with no thermal processing prior to its usage (Šoša, 1989; Baltić 
et al., 2006). By applying the process of vacuuming, the period of safe usage of this product is prolonged to a month at a cooling temperature of $+5^{\circ} \mathrm{C}$. (Ward, 2001). The expiring date of cold smoked fish differs from one manufacturer to another, and they set it themselves. Thus, vacuumed, cold smoked fish is good to be used 21-30 days on the French market, 14 days in Germany, Denmark, and Great Britain, and 60 days in Italy. The expiry date depends on several factors (regime of smoking, salt quantity, temperature, storage) (Cardinal et al., 2004).

The main reason for fish meat spoiling during the period of storage is the appearance and growth of microorganisms, and their metabolic activity. The products of bacterial growth are numerous (amines, sulfides, alcohols, aldehydes, ketones, and organic acids) and they cause the presence of unwanted smell and taste (Leroi et al., 2001).

The total number of bacteria in vacuumed fish and meat products sometimes reaches the value of $10^{7}-10^{8} \mathrm{CFU} / \mathrm{g}$ of meat. The majority of EU countries do not have the legal provisions regulating the number of bacteria in vacuum-packed smoked fish products. In France, the legal regulations on the vacuum-packed smoked fish products allow up to $10^{6} \mathrm{CFU} / \mathrm{g}$ bacteria in these products (Cardinal et al., 2004). However, research findings show that even a number of bacteria up to $10^{8} \log$ CFU/g does not always lead to smoked fish spoiling (Hansen et al., 1996).

Lactobacillus species are present in the largest number and therefore are the most important microorganisms for sustainability, as well as sensory characteristics of cold-smoked, vacuum-packed fish products (Gram and Dalgaard, 2002). Numerous authors (Hansen et al., 1995; Leroi et al., 1998; Vishawanath et al.,1998; Joffraud et al., 2001) examined vacuum-packed, coldsmoked fish products' microflora in their research work.

The data referring to the study of factors relevant to the quality of fish are frequent in literature. In most cases, those data refer to raw material selection, and the influence of, firstly, feeding, and, secondly, ambiental conditions on the quality of fish. The data also refer to genetic factors, sex, mating maturity, life cycle, etc. Studies on the influence of factors relevant to the quality of fish, and relating them to the production process, are frequent. The data presented in literature refer mostly to the effect of microbiological contamination of raw material, effect of slaughtering, salting (the way of salting, content value of salt in the water phase), and smoking (time, temperature, and active matter concentration in the smoke) on the quality of the final product (Leroi et al. 1998; Kolodziejska et al., 2000; Dondero et al., 2004; Stolyhwo i Sikorski, 2005). Special attention is paid to the preservation of smoked fish (bacteriological status, physical and chemical features, sensory characteristics, etc.) (Røra et al., 1999; Cardinal et al., 2004).

Preserving fish by freezing is the most frequent and most practical way of preserving fish meat. The procedure is based on the fact that low temperatures stop microorganism and enzyme activities. This way of preservation affects the fish meat quality to a small extent. It is applied to fish offered to consumers on the market and fish intended to be processed.

The procedure of freezing fish, and later, defrosting and processing it, in effect, gives a final product with a smaller number of bacteria relative to the fish 
processed raw, right after primary processing. The reason for this is the fact that low temperatures reduce the number of microorganisms and have a detrimental effect on their proliferation. Kolodziejska et al. (2000) examined the effect of freezing fish on the final product microbiological status at the end of processing, and during storage. Their findings show that the frozen fish used as raw material for further processing contained a smaller number of bacteria at the skin surface during storage and at the end of processing than the fresh fish used as starting raw material in this experiment. Deng (1979); Sigurgisladottir et al. (2000), Cardinal et al. (2001) examined the effects of fish freezing on its meat structure and, implicitly, on the final product quality.

Only raw fish suitable for consumption fresh as well as frozen, i.e. bacteriologically and chemically sound and harmless to the consumer's health, may be used for smoked fish production. In the circumstances of small processing facilities for smoked fish production, there occurs the necessity, particularly in a good fishing season, for freezing the catch in order to process it, preserved in this way, at times when the season is not so good, or there is no catch at all. Therefore, the goal of the examination was to examine the effect of freezing trout on the microbiological status of stored, vacuum-packed final product.

\section{MATERIALS AND METHODS}

The so-called salmon trout of $1 \mathrm{~kg}$ mass was used in the experiment. Two groups of trout were made for the sake of the experiment: the control one of fresh fish, and the experimental one of previously frozen fish.

After primary processing, the first group of trout were rinsed and dipped into brining dishes (wet salting). The concentration of salt in the brining liquid was $9 \%$. The temperature of air in the room where the brining was done was $4^{\circ} \mathrm{C}$, and the fish were brined for 24 hours. After that, fish was taken out of the brining dishes, drained of the brining liquid, and put onto a grid in the smoke chamber for an hour at a temperature of $20^{\circ} \mathrm{C}$. Smoking was done in automated smoke chambers at a temperature of $28{ }^{\circ} \mathrm{C}$ during the period of 8 hours. After the process of smoking had been finished, the fish cooled for 10 hours at a temperature of $2{ }^{\circ} \mathrm{C}$. Having cooled in this way, the fish was sliced to $0.5 \mathrm{~cm}$ thin slices. The second group of trout, used in the experiment, were rinsed and frozen in a tunnel at a temperature of $-40{ }^{\circ} \mathrm{C}$, after primary processing, and then stored at a temperature of $-20{ }^{\circ} \mathrm{C}$. Each frozen fish was protected by a single plastic bag packaging. In the experiment, fish was unfrozen after ten days in fresh water dishes, during a period of 5 hours. After that, trout underwent the same processing as the control group of trout.

Finally, the plastic bags, each containing approximately $150 \mathrm{~g}$ of fish slices, were vacuumed.

After this, samples of both groups of trout, the control one and the experimental one, were stored for 21 days at a temperature of $4{ }^{\circ} \mathrm{C}$. The microbiological analysis samples were examined on day $0,7,14$, and 21 of storing. 
Determination of the total number of aerobic mesophilic bacteria in the vacuum-packed, smoked fish was done applying the procedure recommended by Roberts et al. (1995).

Determination of the total number of Lactobacillus $s p$. in the final product was done by applying the procedure described in "Microbiological method for the meat industry" (Cook, 1991).

The basic chemical structure test samples of both groups of trout were taken from the original vacuum package on the zero day of testing. The following procedures of basic chemical structure (content value of water, fat, protein, ash) were applied:

- water - determining mass loosing due to drying a homogenized sample at $105 \pm 1^{\circ} \mathrm{C}$ until constant mass value (JUS ISO 1442),

- sodium chloride - Volhard method ( JUS ISO 1841-1).

The water phase salt content value (WPS) is calculated on the grounds of overall content value of salt in the meat and content value of water, applying the formula:

$$
\text { WPS }=\% \text { salt } * 100 / \% \text { salt }+\% \text { water }
$$

Determining $a_{w}$ value was done on the grounds of salt content value in the water phase, applying the formula (Jimenez and Dalgaard, 2004):

$$
a_{w}=1-0.0052471 * \text { WPS }-0.00012206 * \text { WPS }^{2}
$$

\section{RESULTS AND DISCUSSION}

Testing the total number of bacteria in vacuum-packed smoked fish slices has been done by many authors (Hansen, 1995; Hansen et al., 1996; Leroi et al.,1998; Kolodziejska et al., 2000; Dondera et al., 2004). Our findings of testing the change of the total number of bacteria in the control group of trout vacuumpacked slices during the 3 week storage period at $4^{\circ} \mathrm{C}$ show that on day 0 the total number of bacteria in the trout control group slice was (log CFU/g $1.64 \pm 0.23$ ), on day 7 ( $\log \mathrm{CFU} / \mathrm{g} 1.9 \pm 0.51)$, on day $14(\log \mathrm{CFU} / \mathrm{g} 3.55 \pm 0.85)$, and on the last day of testing, after 3 weeks of storage, it was (log CFU/g $2.35 \pm 0.51$ ) (Table 1). A significantly larger total number of bacteria $(p<0.001)$ was determined on day 21 of the storage period relative to the total number of bacteria on day 0 . The rise in number of bacteria in trout slices up to day 14 of storage period, followed by a statistically significant drop of this number until day 21 may be explained by a different kind of bacterial interaction. The substrate competition and antagonism are considered to be the most important at microflora selection in a particular ecological niche (Lone Gram, 1993). This competition between different kinds of bacteria due to the newly formed environmental conditions i.e. due to the decrease and lack of trophic factors necessary for the growth and propagation of bacteria, caused the drop of the total number of bacteria. Contrary to our findings, the findings of another testing Kolodziejska et al. (2000) showed that storing vacuum-packed, smoked trout at somewhat lower temperature $\left(2^{\circ} \mathrm{C}\right)$ did not 
Acta Veterinaria (Beograd), Vol. 59. No. 2-3, 291-302, 2009.

Kilibarda Nataša et al.: Effect of fish freezing on

selected parameters of smoked product quality

have any effects on the microbiological quality of the product. Statistically, the number of bacteria in the fillets did not change significantly during the 3 week storage period, and it was $10 \mathrm{CFU} / \mathrm{g}$. Dondera et al. (2004) found that the total number of bacteria in smoked, vacuum-packed products exceeded even the number of $10^{6} \mathrm{CFU} / \mathrm{g}$ after 3 weeks of storing at $4^{\circ} \mathrm{C}$.

The total number of bacteria in vacuum-packed trout test group on day 0 was $(\log \mathrm{CFU} / \mathrm{g} 1.07 \pm 0.40)$, on day $7(\log \mathrm{CFU} / \mathrm{g} 1.68 \pm 0.22)$, on day 14 (log $\mathrm{CFU} / \mathrm{g} 3.44 \pm 0.50$ ) and after 3 weeks of storing (log CFU/g $2.28 \pm 0.57$ ) (Table 1). A statistically significant difference, with different levels of statistical relevance, was established between the total number of bacteria in the trout test group, stored for 3 weeks. Similar to the change of the total number of bacteria in the trout control group, in the trout test group an increase of bacteria in the first 2 weeks of storing, and then a decrease of this number of bacteria was noted.

Table 1. Change of the total number of bacteria in vacuum-packed, trout slice control and test group during storing at $4{ }^{\circ} \mathrm{C}(\log \mathrm{CFU} / \mathrm{g})$

\begin{tabular}{|c|c|c|}
\hline \multirow{2}{*}{$\begin{array}{c}\text { Time of storage } \\
\text { (d) }\end{array}$} & \multicolumn{2}{|c|}{ Total number of bacteria } \\
\cline { 2 - 3 } & control group & test group \\
\hline \hline 0 & $1.64^{\alpha \mathrm{a}} \pm 0.23$ & $1.07^{\mathrm{a \alpha}} \pm 0.40$ \\
\hline 7 & $1.90^{\alpha \mathrm{ab}} \pm 0.51$ & $1.68^{\mathrm{b} \alpha \gamma} \pm 0.22$ \\
\hline 14 & $3.55^{\mathrm{\beta x}} \pm 0.85$ & $3.44^{\beta} \pm 0.50$ \\
\hline 21 & $2.35^{\mathrm{by}} \pm 0.51$ & $2.28^{\mathrm{a \gamma}} \pm 0.57$ \\
\hline
\end{tabular}

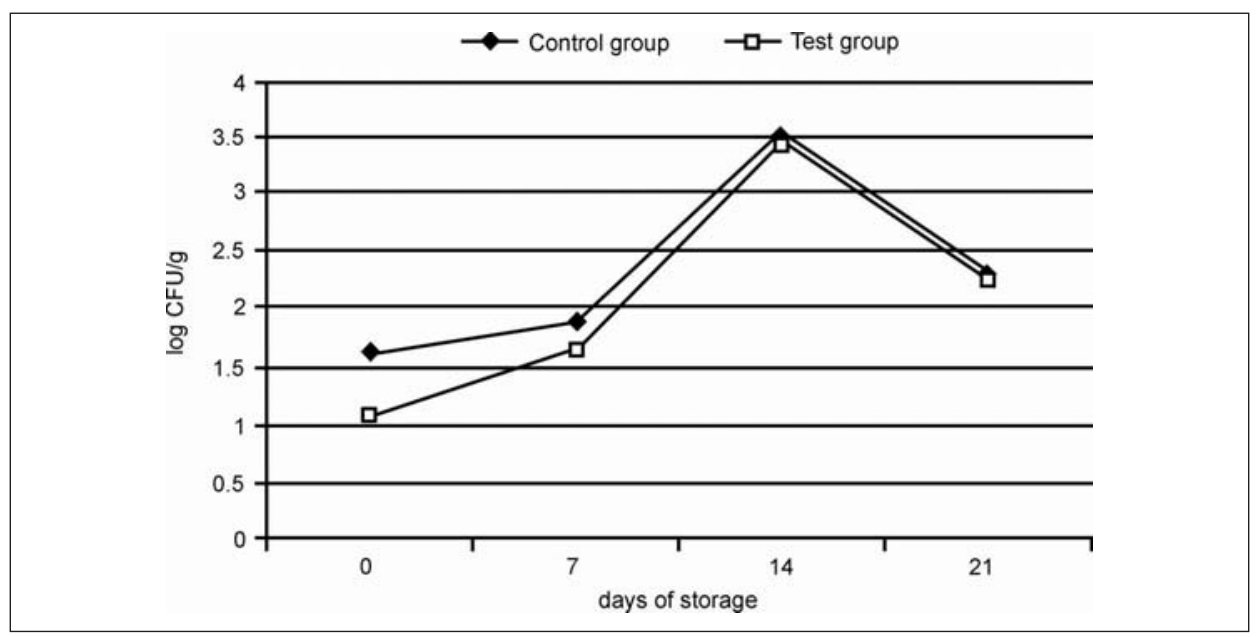

Graph 1. Change of the total number of bacteria in vacuum-packed, trout slice control and test group during storage at $4^{\circ} \mathrm{C}$ temperature 
Although the total number of bacteria in the trout control group was higher relative to the number of bacteria in the trout test group, the statistical relevance of the total number of bacteria difference was determined only on day $0(p<0.05)$ of testing (Table 2). The change in total number of bacteria in vacuum-packed trout slice control and test group during the storage period, at $4{ }^{\circ} \mathrm{C}$ temperature, is presented in Graph 2.

Table 2. Statistical relevance of difference (T-test) between total number of bacteria in control group and test group of vacuum-packed, smoked, trout slices stored at $4{ }^{\circ} \mathrm{C}(\log \mathrm{CFU} / \mathrm{g})$

\begin{tabular}{|c|c|c|c|c|}
\hline Group & Day 0 & Day 7 & Day 14 & Day 21 \\
\hline \hline Control & $1.64^{\mathbf{a}} \pm 0.24$ & $1.89 \pm 0.51$ & $3.54 \pm 0.85$ & $2.35 \pm 0.51$ \\
\hline Test & $1.07^{\mathbf{b}} \pm 0.40$ & $1.68 \pm 0.22$ & $3.44 \pm 0.50$ & $2.28 \pm 0.57$ \\
\hline
\end{tabular}

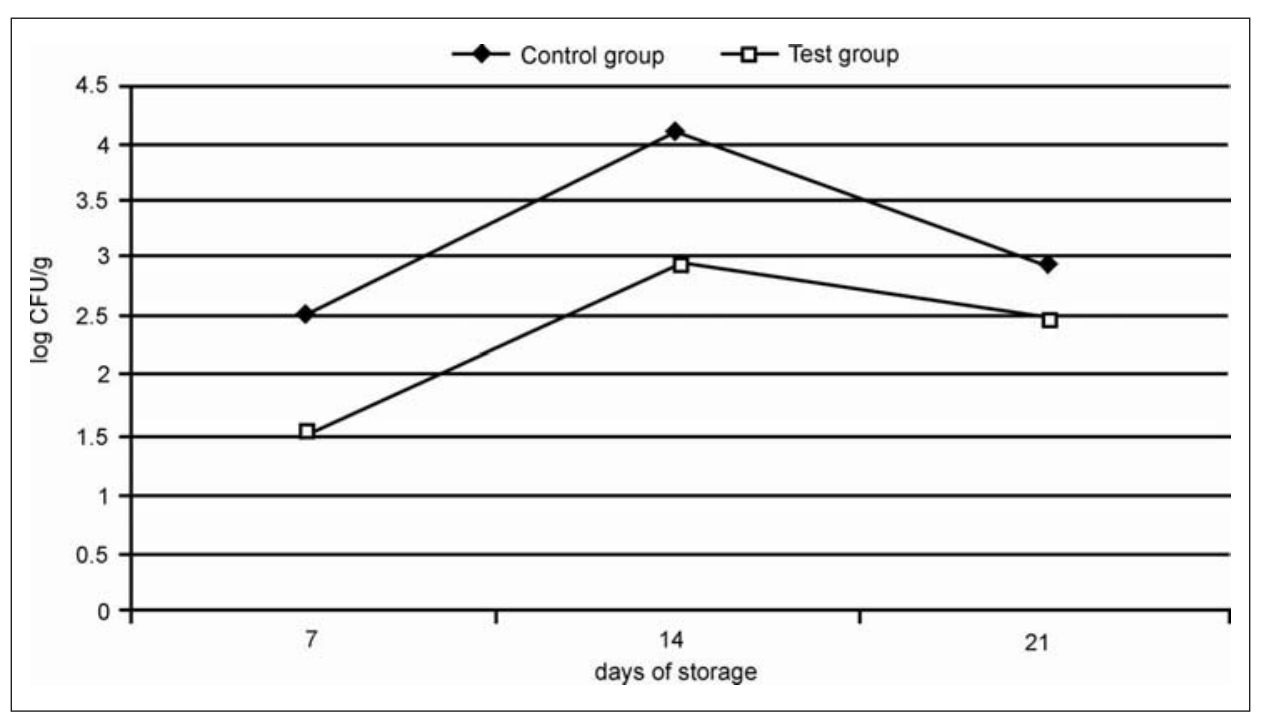

Graph 2. The modification of total number of Lactobacillus sp. in both control and test group vacuum-packed smoked trout slices during storing at $4{ }^{\circ} \mathrm{C}(\log \mathrm{CFU} / \mathrm{g})$

The total number of bacteria in vacuum-packed, smoked, fish products as established by Hansen et al. (1995) in their researches raised up to the value of $10^{8} \mathrm{CFU} / \mathrm{g}$ on day 21 of storing at $5^{\circ} \mathrm{C}$ temperature, but they also found that this number of bacteria does not necessarily lead to product spoilage. Regarding the fact that the total number of bacteria does not indicate specific microorganisms that can cause decay (or pathogens) nor is it in correlation with the first signs of product spoilage, numerous scientists directed their research to identifying specific microorganisms that cause vacuum-packed, smoked fish product decay 
Acta Veterinaria (Beograd), Vol. 59. No. 2-3, 291-302, 2009.

(Hansen et al., 1995; Hansen et al., 1996; Hansen et al., 1998; Leroi et al., 1998; Lyhs et al., 1999; Hyytiä et al., 1999; Gonzáles et al., 2002; Cardinal et al., 2004; Dondera et al., 2004; Espe et al., 2004).

By investigating the bacterial composition of vacuum-packed smoked fish products, Gonzalez et al. (2002) established that the most representative group of microorganisms in these products were Lactobacillus species, and the most often isolated and identified were: L. sakei, L. curvatus, L. homohiochii, L. plantarum, L. delbrueckii, L. casei, L. coryneformis, L. alimentarius. By investigating the microflora in vacuum-packed cold-smoked products, Leroi et al. (1998) confirmed that for the first two weeks of storage, the microflora was composed of Gram (-) bacteria, after what their number was progressively decreasing, and the Gram $(+)$ microorganisms became the dominant ones, especially Lactobacillus $s p$. Lactobacillus inhibit the growth of other bacteria by producing lactic acid, lowering the $\mathrm{pH}$ of the environment, producing bacteriocin, but as well as by competition for the nutrients. As a result, their presence in vacuum-packed products can contribute in some way to extending the viability of vacuum-packed products (Gram and Dalgaard, 2002).

The results of our research show that the total number of Lactobacillus sp. in both product groups during storage at $4^{\circ} \mathrm{C}$ statistically grew during the first two weeks of storage, (log CFU/g $2.52 \pm 0.06)$ (log CFU/g 4.22 \pm 0.11 ), respectively, but after that started to decrease, and on day 21 of storage it was log CFU/g $2.84 \pm 0.28$. On day 7 , the total number of Lactobacillus $s p$. (log CFU/g $1.58 \pm 0.16)$ in the fillets was significantly lower $(p<0.001)$ than the total number of Lactobacillus bacteria species stored for 14 days (log CFU/g $2.91 \pm 0.20$ ), but also statistically lower $(p<0.05)$ than the total number of Lactobacillus bacteria species in the slices that were stored for 21 days (log CFU/g $2.44 \pm 0.42$ ) (Table $3)$. The total number of Lactobacillus species in the slices after 14 days of storage was statistically $(p<0.05)$ higher than the total number of species in the slices that were stored for 21 days. Among the total number of Lactobacillus species in the test group trout fillets stored for three weeks, it was established that there were significant differences, with different levels of statistical significance (Table 3). Statistical significance of the difference was ascertained among the total number of Lactobacillus species in both test and control group on day 7 of storage $(p<0.001)$, as well as after two weeks $(p<0.001)$. During the third week of storage, there were no statistically significant differences (Table 4).

Table 3. The modification of total number of Lactobacillus sp. in both control and test group vacuum-packed smoked trout slices during storing at $4{ }^{\circ} \mathrm{C}(\log \mathrm{CFU} / \mathrm{g})$

\begin{tabular}{|c|c|c|}
\hline \multirow{2}{*}{$\begin{array}{c}\text { Time of storage } \\
\text { (d) }\end{array}$} & \multicolumn{2}{|c|}{ Total number of Lactobacillus sp. } \\
\cline { 2 - 3 } & control group & test group \\
\hline \hline 7 & $2.52^{\alpha \mathbf{x}} \pm 0.06$ & $1.58^{\alpha} \pm 0.16$ \\
\hline 14 & $4.22^{\beta} \pm 0.11$ & $2.91^{\beta \mathbf{a}_{ \pm}} \pm 0.20$ \\
\hline 21 & $2.84^{\alpha \mathbf{y}} \pm 0.28$ & $2.44^{\beta \mathbf{b}} \pm 0.42$ \\
\hline
\end{tabular}


Table 4. Statistical relevance of difference (T-test) between total number of Lactobacillus species in both control and test group vacuum-packed smoked trout slices during storing at $4{ }^{\circ} \mathrm{C}(\log \mathrm{CFU} / \mathrm{g})$

\begin{tabular}{|l|c|c|c|}
\hline Group & day 7 & day 14 & day 21 \\
\hline \hline Control & $2.52^{\alpha} \pm 0.06$ & $4.22^{\alpha} \pm 0.39$ & $2.84 \pm 0.28$ \\
\hline Test & $1.58^{\beta} \pm 0.16$ & $2.91^{\beta} \pm 0.60$ & $2.44 \pm 0.44$ \\
\hline
\end{tabular}

Graph 2. shows modifications of the total number of Lactobacillus sp. in both test and control group during the three weeks of storage at $4{ }^{\circ} \mathrm{C}(\log \mathrm{CFU} / \mathrm{g})$.

Dondero et al. (2004), Hansen et al. (1998), Leroi et al. (1998) were researching the toal number of Lactobacillus species in vacuum-packed cold smoked products during three weeks of storage. Nevertheless, the number of Lactobacillus species, according to their results, was in the range of $10^{3}$ to $10^{8} \mathrm{log}$ $\mathrm{CFU} / \mathrm{g}$ after three weeks of storage at $4^{\circ} \mathrm{C}$. The reason for these unequal results is the problem of not having standards and possibility for maintaining the equal quality of vacuum-packed smoked trout in EU countries, as well as in our country.

Kolodziejska et al. (2000) were researching the microbiological status of the finished product at the end of the production process and during storage. Their results show that the frozen fish as an initial raw material at the end of production process and during storage had lower number of bacteria on the surface than the fresh catch that was used as an initial raw material in this experiment.

Just this conserving activity of low temperatures on the microflora of the initial raw material of the test group trout had influence on our experiment to get the product with lower number of bacteria, as well as Lactobacillus $s p$.

The water phase salt content (WPS) in control and test group of vacuumpacked, smoked trout was calculated based on the content values of salt and water in the control and test group products. The WPS in control group of vacuum-packed, smoked trout slices $(4.58 \pm 1.42 \%)$ was statistically significantly lower $(p<0.001)$ relative to the WPS in the test group of vacuum-packed, smoked trout slices (5.93 $\pm 0.61 \%$ ) (Table 5). Based on the applied formula, the calculated $a_{w}$ value in the control group was 0.98 , and the value in the test group products was lower - 0.97, as presented in Table 5.

Table 5. Average content value of water, salt, of WPS content value and $a_{w}$ value and statistical relevance of difference between the test and control group of trout

\begin{tabular}{|l|c|c|c|c|}
\hline Group & Water & Salt & WPS & $a_{\mathrm{w}}$ \\
\hline \hline Control & $71.00^{\mathrm{a}} \pm 2.43$ & $3.25^{\alpha} \pm 1.01$ & $4.36^{\alpha} \pm 1.29$ & 0.98 \\
\hline Test & $72.24^{\mathrm{b}} \pm 1.93$ & $4.27^{\beta} \pm 0.35$ & $5.59^{\beta} \pm 0.54$ & 0.97 \\
\hline
\end{tabular}

The average content value of salt in the control group vacuum-packed, smoked trout fillets was $3.25 \pm 1.01 \%$ and was significantly lower $(p<0.001)$ than the average content value of salt in the test group trout fillets $(4.27 \pm 0.35 \%)$. 
Acta Veterinaria (Beograd), Vol. 59. No. 2-3, 291-302, 2009.

Kilibarda Nataša et al.: Effect of fish freezing on

selected parameters of smoked product quality

Sigurgisladottir et al. (2000a), Cardinal et al. (2001) had similar findings of the content of salt in fresh and frozen raw material samples in their researches. As already pointed to, the higher content value of salt in the test group of trout is explained by a better penetration of salt into meat cells that underwent a change of structure due to freezing and this, in effect, increased the diffusion of salt into the meat.

Goulas et al. (2005) testing showed that the content value of neither salt nor water significantly changed during the 30 day period of storage at $2^{\circ} \mathrm{C}$.

Deng (1977), Sigurgisladottir et al. (2000), Cardinal et al. (2001), tested the effect of raw material choice on the penetration of salt into fish meat. Their findings show that salt penetrates previously frozen fish meat better as the cell structures of which have been changed during freezing causing, in effect, a larger salt diffusion into the meat.

The content of salt in the sample plays a significant role in determining the product's expiring date, considering the well-known preserving effect of salt. When salt ions penetrate the flesh, they may attach to, and interact with protein molecules. When there are no such ions, proteolytic microorganism enzymes might attach to those molecules. In this way, the ions block the formation of links and prevent the action of bacterial enzymes. In addition, chloride ions are toxic to certain kinds of microorganisms (Hansen et al., 1995; Goulas et al., 2005). Research shows that, during the storage period, the samples with a larger content of salt in the water phase were fit for consumption for at least 2-3 weeks more compared to the ones with a smaller content of salt, at which the process of decay started much earlier. Also, the concentrations of all disintegration products, the overall evaporating nitrogen substance, tri methanol amine, hypoxanthine, ethanol, and organic acids, as well as the total number of bacteria were increasing during the storage period. The increase in concentration of these compounds during the storage period, as well as the total number of bacteria were less expressed in all samples that had a higher concentration of salt (Hansen et al., 1995). Yanar et al. (2006) also proved the effect of salt concentration to the preservation of product. Their findings show that samples with the highest concentration of salt were well preserved the longest during the period of storage.

The preserving effect of salt is grounded on the effect that it lowers $a_{w}$ value in fish meat, reducing the content of water accessible to microorganisms. Lowering $a_{w}$ value slows down bacteria propagation, which stops completely below a certain value, but it very rarely causes death of bacterial cells. Based on the applied formula, the $a_{w}$ value in the control group of products was determined to be 0.98 , and in the test group it was 0.97 , which may be explained by the change in proteins during freezing which, in effect, caused the increase of salt diffusion into cells (Table 5). The $a_{w}$ value in both groups of products was not lower than 0.97 , the growth of microorganisms was not completely stopped (Kolodziejska et al., 2000). The lower $\mathrm{a}_{\mathrm{w}}$ value in the test group of trout products is the result of a higher percentage of salt in the water stage of this group of products. 


\section{CONCLUSION}

The findings of our research show that raw material freezing is appropriate and, when the catch is very good, even recommendable in conditions of smaller processing capacities. It is so because cold smoked, vacuum-packed products, produced from raw material that had been frozen prior to processing, had a smaller total number of both bacteria and lactobacilli at the beginning of the storing period, as well as at the end of it. Moreover, the change happening in fish meat structure as an effect of freezing temperature, induced the change of salt content, subsequently changing the content of salt in the water stage, as well (the content of salt in the water phase of vacuum-packed, smoked slices produced from fresh fish was statistically considerably smaller relative to the content of salt in the water stage of vacuum-packed, smoked slices produced from frozen fish), which also contributed to the prolonged period of time during which the vacuumpacked, smoked fillets produced from frozen fish were fit to consume.

Address for correspondence:

Mr Sc. Nataša Kilibarda

Veterinary Specialist Institute "Subotica"

Segedinski put 88

24000 Subotica

Serbia

E-mail: kilibardanatasa@vsisu.co.rs

\section{REFERENCES}

1. Baltić ŽM, Kilibarda Nataša, Gopčević Kristina, Dimitrijević Mirjana, Sando D, 2006, Činioci od značaja za kvalitet dimljene ribe, Zbornik kratkih sadržaja, 12. Savjetovanje veterinara Republike Srpske, Teslić.

2. Cardinal M, Knockaert C, Torrissen O, Sigurgisladottir S, Mørkøre T, Thomassen M et al, 2001, Relation of smoking parameters to the yield, colour and sensory quality of smoked Atlantic salmon (Salmo salar), Food Res Intern, 34, 537-50.

3. Cardinal Mireille, Gunnlaugsdottir Helga, Bjoernevik Marit, Ouisse Alexandra, Vallet JL et al, 2004, Sensory characteristics of cold-smoked Atlantic salmon (Salmo salar) from European market and relationships with chemical, physical and microbiological measurements, Food Res Intern, 37, 181-93.

4. Cook R, 1991, Microbiological method for the meat industry, MIRINZ, Second Ediction of Meat Industry Research Institute of New Zeland, Hamilton, New Zeland.

5. Deng JC, 1979, Effects of freezing and frozen storage on salt penetration into fish muscle immersed in brine, J Food Sci Technol, 32, 159-68.

6. Dondero M, Cisternas F, Carvajal L, Simpson R, 2004, Changes in quality of vacuum-packed coldsmoked salmon (Salmo salar) as a function of storage temperature, Food Chem, 87, 543-50.

7. Espe M, Nortvedt R, Lie Ø, Hafsteinsson H, 2001, Atlantic salmon (Salmo salar, L.) as raw material for smoking industry. I: effect of different salting methods on the oxidation of lipids, Food Chem, $75,411-6$.

8. Gimenez B, Dalgaard P, 2004, Modelling and predicting the simultaneous growth of Listeria monocytogenes and spoilage microorganisms in cold smoked salmon, J Appl Microbiol, 96, 96-109.

9. Gonzáles-Rodrígez MN, Sanz J, Santos JA, Otero A, García-López ML, 2002, Numbers and types of microorganisms in vacuum-packed cold-smoked freshwater fish at the retail level, Intern $J$ Food Microbiol, 77, 161-8. 
Acta Veterinaria (Beograd), Vol. 59. No. 2-3, 291-302, 2009.

10. Goulas A, Kontominas M, 2005, Effect of salting and smoking-method on the keeping quality of chub mackerel (Scomber japonicus): biochemical and sensory attributes, Food Chem, 93, 51120.

11. Gram L, Dalgaard P, 2002, Fish spoilage bacteria-problems and solution. Curr Opp Biotechnol, 13, 262-6.

12. Hansen LT, Røntved SD, Huss HH, 1998, Microbiological quality and shelf life of cold-smoked salmon from three different processing plants, Food Microbiol, 15, 137-50.

13. Hansen LT, Gill T, Røntved SD. Huss HH, 1996, Importance of autolysis and microbiological activity of quality of cold-smoked salmon, Food Res Intern, 29, 181-8.

14. Hansen LT, Gill T, Huss HH, 1995, Effects of salt and storage temperature on chemical, microbiological and sensory changes in cold-smoked salmon, Food Res Intern, 28, 123-30.

15. Hyytiä E, Hielm S, Mokkila M, Kinnunen A, Korkeala H, 1999, Predicted and observed growth and toxigenesis by Clostridium botulinum type $\mathrm{E}$ in vacuum-packaged fishery product challenge tests, Intern J Food Microbiol, 47, 161-9.

16. Joffraud JJ, Leroi F, Roy C, Berdague JL, 2001, Characterization of volatile compounds produced by bacteria isolated from the spoilage flora of cold-smoked salmon, Intern J Food Microbiol, $66,175-84$.

17 Kolodziejska I, Niecikowska C, Januszewska E, Sikorski ZE, 2000, The Microbial and Sensory Quality of Mackerel Hot Smoked in Mild Conditions. Lebensm-Wiss Technol, 35, 87-92.

18. Leroi F, Joffraud J, Chevalier F, Cardinal M, 2001, Research of quality indices for cold-smoked salmon using a stepwise multiple regression of microbiological counts and physics-chemical parameters, J Appl Microbiol, 90, 578-88

19. Leroi F, Joffraud J. Chevalier F, Cardinal M, 1998, Study of the microbial ecology of cold-smoked salmon during storage at $8^{\circ} \mathrm{C}$, Intern $\mathrm{J}$ Food Microbiol, 39, 111-21.

20. Lone G, 1993, Inhibitory effects against pathogenic and spoilage bacteria of Pseudomonas strains isolated from spoiled and fresh fish, Appl Environmen Microbiol, 59, 219-23.

21. Lyhs U, Björkroth J, Korkeala $H$, 1999, Characterisation of lactic acid bacteria from spoiled, vacuum-packed, cold-smoked rainbow trout using ribotyping, Intern J Food Microbiol, 52, 7784.

22. Roberts, D, Hooper, W, Greenwood, M, 1995, Practical Food Microbiology, second edition. Public Health Laboratory Service, London.

23. Røra Anna Maria, Kvale Audil, Mørkøre Rørvik, Kjell-Arne, Steien SH, Thomassen MS, 1999, Process yield, colour and sensory quality of smoked Atlantic salmon (Salmo salar) in relation to raw material characteristics. Food Res Intern, 31, 601-9.

24. Sigurgisladottir S, Ingvarsdottir H, Torrissen OJ, Cardinal M, Hafsteinsson H, 2000, Effects of freezing/thawing on the microstructure and the texture of smoked Atlantic salmon (Salmo salar). Food Res Intern, 33, 857-65.

25. Stolyhwo A, Sikorski EZ, 2005, Polycyclic aromatic hydrocarbons in smoked fish - a critical review, Food Chem, 91, 303-11.

26. Šoša B, 1989, Higijena i tehnologija prerade morske ribe, Školska knjiga, Zagreb.

27. Vishwanatah W, Lilabati H, Bije, M, 1998, Biochemical, nutritional and microbiological quality of fresh and smoked mud eel fish Monopterus albus-a comparative study, Food Chem, 61, 151-6.

28. Ward DR, 2001, Description of the situation, J Food Sci, 66, 7, 1067-71.

29. Yanar Y, Celik M, Akamca E, 2006, Effects of brine concentration on shelf-life of hot-smoked tilapia (Oreochromis niloticus) stored at $4{ }^{\circ} \mathrm{C}$, Food Chem, 97, 244-7. 


\title{
UTICAJ ZAMRZAVANJA RIBE NA ODABRANE PARAMETRE KVALITETA DIMLJENOG PROIZVODA
}

\author{
KILIBARDA NATAŠA, BALTIĆ ŽM, DIMITRIJEVIĆ MIRJANA, KARABASIL N \\ i KIŠKAROLJ F
}

SADRŽAJ

U uslovima malih preradnih kapaciteta za proizvodnju dimljene ribe nameće se potreba, u sezonama većeg izlova, za zamrzavanjem ribe i njena dalja prerada u vremenu kada je taj izlov mali, ili ga nema. Zbog toga je cilj našeg istraživanja bio da se ispita uticaj zamrzavanja ribe na odabrane parametre kvaliteta hladno dimljenih vakuumiranih fileta pastrmke. Za eksperiment su formirane dve grupe pastrmki: kontrolna od sveže ribe i ogledna od prethodno zamrznute ribe. U toku tri nedelje skladištenja proizvoda dimljene ribe pri temperaturi od $4{ }^{\circ} \mathrm{C}$ praćena je promena ukupnog broja bakterija i ukupan broj laktobacila, a na kraju proizvodnje utvrđen je sadržaj vode i soli, izračunat je sadržaj soli u vodenoj fazi i $a_{w}$ vrednost (aktivnost vode). Ispitivanjem bakteriološkog statusa obe grupe proizvoda, utvrđeno je da je i ukupan broj bakterija i ukupan broj laktobacila u uzorcima, tokom skladištenja, bio manji kod uzoraka proizvedenih od zamrzavane ribe. Prosečan sadržaj vode, $\mathrm{NaCl}$, kao i sadržaj soli u vodenoj fazi u vakuumiranim dimljenim filetima proizvedenim od zamrznute ribe bio je statistički značajno veći od sadržaja vode, soli i sadržaja soli u vodenoj fazi u poređenju sa uzorcima proizvedenim od sveže ribe. Rezultati naših istraživanja ukazuju da je opravdano, čak i poželjno, u proizvodnji dimljenih fileta ribe koristiti sirovinu koja je prethodno bila zamrznuta. 